\title{
Effect of Calcium Content on the Microstructure, Hardness and In-Vitro Corrosion Behavior of Biodegradable Mg-Ca Binary Alloy
}

\author{
Shervin Eslami Harandi ${ }^{\mathrm{a}}$,Mohammad Mirshahi ${ }^{\mathrm{a}}$, Shahriar Koleini ${ }^{\mathrm{a}}$,Mohd Hasbullah Idris ${ }^{\mathrm{a} *}$, \\ Hassan Jafari ${ }^{\mathrm{a}, \mathrm{b}}$, Mohammed Rafiq Abdul Kadir ${ }^{\mathrm{c}}$ \\ a'Department of Materials Engineering, Faculty of Mechanical Engineering, \\ Universiti Teknologi Malaysia, 81310, Skudai, Johor, Malaysia \\ ${ }^{\mathrm{b} D e p a r t m e n t ~ o f ~ M a t e r i a l s ~ E n g i n e e r i n g, ~ F a c u l t y ~ o f ~ M e c h a n i c a l ~ E n g i n e e r i n g, ~}$ \\ Shahid Rajaee University, Tehran, 16785-136, Iran \\ 'Department of Biomechanics and Biomedical Materials, Faculty of Biomedical Engineering and Health \\ Sciences, Universiti Teknologi Malaysia, 81310, Skudai, Johor, Malaysia
}

Received: March 8, 2012; Revised: June 6, 2012

\begin{abstract}
Effect of calcium addition on microstructure, hardness value and corrosion behavior of five different $\mathrm{Mg}$-xCa binary alloys ( $\mathrm{x}=0.7,1,2,3,4 \mathrm{wt}$. $(\%)$ ) was investigated. Notable refinement in microstructure of the alloy occurred with increasing calcium content. In addition, more uniform distribution of $\mathrm{Mg}_{2} \mathrm{Ca}$ phase was observed in $\alpha-\mathrm{Mg}$ matrix resulted in an increase in hardness value. The in-vitro corrosion examination using Kokubo simulated body fluid showed that the addition of calcium shifted the fluid $\mathrm{pH}$ value to a higher level similar to those found in pure commercial $\mathrm{Mg}$. The high $\mathrm{pH}$ value amplified the formation and growth of bone-like apatite. Higher percentage of $\mathrm{Ca}$ resulted in needle-shaped growth of the apatite. Electrochemical measurements in the same solution revealed that increasing $\mathrm{Ca}$ content led to higher corrosion rates due to the formation of more cathodic $\mathrm{Mg}_{2} \mathrm{Ca}$ precipitate in the microstructure. The results therefore suggested that $\mathrm{Mg}-0.7 \mathrm{Ca}$ with the minimum amount of $\mathrm{Mg}_{2} \mathrm{Ca}$ is a good candidate for bio-implant applications.
\end{abstract}

Keywords: magnesium alloys, biomaterials, SBF, microstructure, corrosion, hardness

\section{Introduction}

Potential materials for the use in medical applications need to be compatible with the human body without generating harmful impacts ${ }^{1}$. In recent years, there has been an indisputable tendency to use magnesium and its alloys in implants or bone grafts as they have mechanical properties similar to human bone and are biocompatible and biodegradable both in-vivo and in-vitro ${ }^{2-4}$. Furthermore, in comparison with polymeric biodegradable implants, tensile yield strength and Young's modulus are higher in magnesium and its alloys ${ }^{5}$. The disadvantages of magnesium usage as implant applications are high corrosion rates and hydrogen evolution $^{6}$. The addition of alloying elements, namely aluminum and rare earths, was found to be an appropriate remedy to overcome the above deficiencies ${ }^{7-9}$. However, aluminum is possibly a harmful element to neurons and osteoblasts that expedites dementia and Alzheimer's diseases ${ }^{10}$. Similarly, rare earth elements such as $\mathrm{Pr}$, Ce and $\mathrm{Y}$ increase the likelihood of hepatotoxicity ${ }^{11}$. In addition, aluminum and rare earth elements exceed a particular level required for optimization of biodegradable $\mathrm{Mg}$ alloys leading to an unpleasant impact on DNA factors?

Based on the latest investigations, $\mathrm{Ca}, \mathrm{Mn}$ and $\mathrm{Zn}$ elements are appropriate constituents that gradually degrade within the human body, along with magnesium,

*e-mail: hsbullah@fkm.utm.my without raising the serum $\mathrm{Mg}^{2+}$ level or damaging important organs such as kidneys ${ }^{7,12,13}$. Such particular elements, especially calcium, are contributing factors to control corrosion rate of magnesium alloys ${ }^{14}$. Ca is also one of the most important and necessary element of human bone, particularly in terms of chemical signaling with different cells $^{6}$. Moreover, $\mathrm{Ca}$ as an inexpensive alloying element with a low density $\left(1.55 \mathrm{~g} \mathrm{~cm}^{-3}\right)$ similar to bone is able to produce hydroxyapatite (HA) during corrosion in the body and accelerate bone healing ${ }^{13,15}$. Therefore, it is a contributing approach to develop $\mathrm{Mg}$-Ca alloy with good corrosion resistance in biomedical applications of magnesium. The aim of this study is to investigate the effect of different percentages of calcium on the corrosion and electrochemical behavior of binary $\mathrm{Mg}$-Ca alloys in Kokubo simulated body fluid as well as hardness and microstructure characteristics.

\section{Experimental}

\subsection{Fabrication and sample preparation}

Pure commercial magnesium ingot $(99.9 \% \mathrm{Mg}$ ) and calcium-magnesium master alloy $(\mathrm{Mg}-30 \mathrm{Ca})$ were melted in a mild steel crucible at $740{ }^{\circ} \mathrm{C}$ in an argon gas protected environment using an induction furnace (Inductotherm). The molten metal was poured into a mild steel simple mould 
preheated at $200{ }^{\circ} \mathrm{C}$. The chemical composition of the as-cast $\mathrm{Mg}$-xCa alloys was analyzed by energy dispersive spectrometer (EDS, Zeiss Supra 33VP) at 3 different sample locations.

\subsection{Microstructural characterization}

Samples sized at $20 \times 20 \mathrm{~mm}$ were cut from pure magnesium and the as-cast alloys. They were then mechanically polished after being ground up to 4000 grit prior to microscopic analysis. Optical microscope (Olympus BX60), SEM/EDS and X-ray diffractometer (XRD, Siemens-D500, $\mathrm{Cu} \mathrm{K} \alpha$ radiation generated at $40 \mathrm{kV}$ and $35 \mathrm{~mA}$ ) were used for microstructural characterization. The average grain size of pure magnesium and the as-cast alloys was measured according to ASTM E 112-96 standard using the mean lineal intercept with five different readings for each micrograph.

\subsection{Hardness test}

A Vickers hardness testing machine (Matsuzawa, DVK-2) was used to measure hardness value of the prepared samples according to ASTM E92-82 standard. The load, loading time and loading speed of the machine were set at $10 \mathrm{~kg}, 10 \mathrm{~s}$ and $50 \mu \mathrm{m} / \mathrm{sec}$, respectively.

\subsection{Immersion test}

The immersion test was performed according to ASTM G31-72 standard in the Kokubo simulated body fluid (SBF) for 72 hours. The chemical composition of Kokubo solution as compared to human blood plasma is given in Table $1^{16}$. The test was carried out inside an incubator (AMBI-100) at a maintained temperature of $37 \pm 0.5^{\circ} \mathrm{C}$. Samples measuring $13 \times 11 \times 5 \mathrm{~mm}$ were cut from the pure magnesium and the cast alloys and ground up to 2400 grit by silicon carbide papers. The $\mathrm{pH}$ value of the SBF was initially adjusted to 7.73. During the experiment, the samples were removed from the solution at 12 hour intervals, washed with distilled water and dried at room temperature. In addition, the $\mathrm{pH}$ of the SBF was monitored during the immersion test at the mentioned intervals. The morphology of the corrosion products formed on the surface of the samples was examined by SEM/EDS.

\subsection{Electrochemical measurement}

The immersion test was complemented with an electrochemical polarization test. This test was carried out by a potentiodynamic system (Parstat 2263) operated by PowerCORR software (at a scan rate of $0.9 \mathrm{mV} / \mathrm{sec}$ ) to study the degradation behavior of the pure magnesium as well as the alloys according to ASTM G5-94 standard. A volume of $400 \mathrm{~mL}$ of SBF with a $\mathrm{pH}$ of 7.73 maintained at $37^{\circ} \mathrm{C}$ was used for the test solution. A typical three-electrode system consisting of graphite rod, saturated calomel electrode (SCE) and specimen $\left(1 \mathrm{~cm}^{2}\right.$ exposed area) were used as the counter, reference and working electrodes, respectively. $\mathrm{SiC}$ paper was used to polish the samples up to 2400 grit followed by washing them with distilled water and drying in hot air prior to the experiment.

\section{Results and Discussion}

\subsection{Microstructural analysis}

Table 2 gives the chemical composition of the as-cast $\mathrm{Mg}$-xCa alloys. It can be seen that the calcium percentage of the as-cast alloys follows the nominal composition of the alloys indicating acceptable casting procedure. Figure 1 shows the optical microstructures of pure magnesium and produced $\mathrm{Mg}-\mathrm{Ca}$ alloys containing different calcium content. According to the micrographs, it can be clearly stated that the addition of calcium element caused a decrease in the grain size of magnesium. In addition, further grain refinement was observed with increasing calcium content in binary $\mathrm{Mg}-\mathrm{Ca}$ alloys (Table 3).

The grain refinement was due to the restriction of grain growth through the formation of a significant constitutional undercooling in an area immediately adjacent to the solid/ liquid interface. In addition, according to the equilibrium phase diagram of binary $\mathrm{Mg}-\mathrm{Ca}$ alloys, the volume fraction of $\mathrm{Mg}_{2} \mathrm{Ca}$ intermetallic increased with increasing calcium content, as can be clearly observed from the SEM images of $\mathrm{Mg}-1 \mathrm{Ca}$ and $\mathrm{Mg}-3 \mathrm{Ca}$ alloys in Figures 2a, b, respectively. In addition, the images show distribution of $\mathrm{Mg}_{2} \mathrm{Ca}$ in the form of eutectic phase among the interdendrites areas and along grain boundaries. In other words, in the course of solidification, the remaining liquid was enriched with calcium and then solidified as $\alpha-\mathrm{Mg}+\mathrm{Mg}_{2} \mathrm{Ca}$ eutectic phase (Figure 2c). Therefore, the alloys with higher percentage of $\mathrm{Ca}$ offered better resistance against grain growth.

The EDS analysis shown in Figure 3 illustrates calcium content of $\alpha-\mathrm{Mg}$ matrix and $\mathrm{Mg}_{2} \mathrm{Ca}$ phase. Figure 3a concludes that a solid solution of $0.7 \%$ calcium in magnesium was formed in the alloy matrix together with traces amount of $\mathrm{Mg}_{2} \mathrm{Ca}$ phase in the microstructure. As a result, further increase in $\mathrm{Ca}$ content caused precipitation

Table 1. Ion concentrations of the simulated body fluid and human blood plasma.

\begin{tabular}{lcc}
\hline \multirow{2}{*}{ Ion } & \multicolumn{2}{c}{ Concentration $\left(\mathbf{m m o l . d m}^{-3}\right)$} \\
\cline { 2 - 3 } & Simulated body fluid (SBF) & Human blood plasma \\
\hline $\mathrm{Na}^{+}$ & 142.0 & 142.0 \\
$\mathrm{~K}^{+}$ & 5.0 & 5.0 \\
$\mathrm{Mg}^{2+}$ & 1.5 & 1.5 \\
$\mathrm{Ca}^{2+}$ & 2.5 & 2.5 \\
$\mathrm{Cl}^{-}$ & 147.8 & 103.0 \\
$\mathrm{HCO}_{3}^{-}$ & 4.2 & 27.0 \\
$\mathrm{HPO}_{4}^{2-}$ & 1.0 & 1.0 \\
$\mathrm{SO}_{4}^{2-}$ & 0.5 & 0.5 \\
\hline
\end{tabular}

Table 2. Chemical composition of the as-cast $\mathrm{Mg}$-xCa alloys.

\begin{tabular}{ccccccc}
\hline \multirow{2}{*}{ Mg-xCa alloy } & \multicolumn{5}{c}{$\mathbf{x}$} \\
\cline { 3 - 7 } & & $\mathbf{0 . 7}$ & $\mathbf{1}$ & $\mathbf{2}$ & $\mathbf{3}$ & $\mathbf{4}$ \\
\hline \multirow{2}{*}{ Elements } & $\mathrm{Mg}$ & 98.3 & 97.7 & 95.2 & 93.9 & 92.8 \\
& $\mathrm{Ca}$ & 0.74 & 1.08 & 1.98 & 3.03 & 3.98 \\
\hline
\end{tabular}


of considerable amount of $\mathrm{Mg}_{2} \mathrm{Ca}$. XRD analysis of the alloys detected only the presence of $\mathrm{Mg}_{2} \mathrm{Ca}$ phase and $\alpha-\mathrm{Mg}$ (Figure 4). The diffraction intensity of $\mathrm{Mg}_{2}$ Ca phase at $2 \theta=70.11^{\circ}$, which corresponds to (313) crystallographic plane, increased with rising calcium percentage confirming an increase in the amount of $\mathrm{Mg}_{2}$ Ca phase.

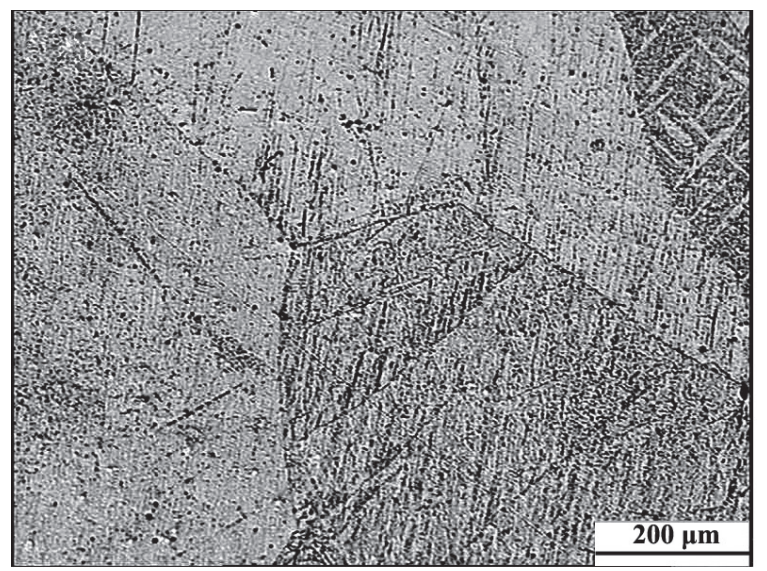

(a)

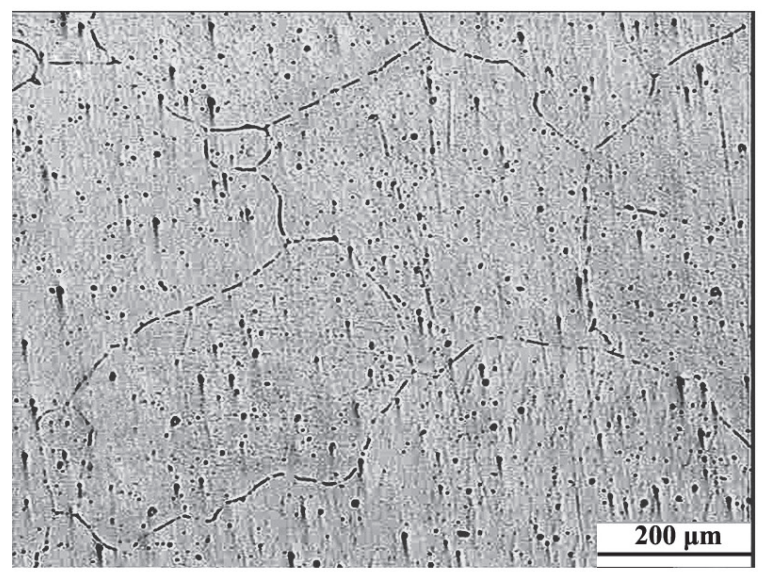

(c)

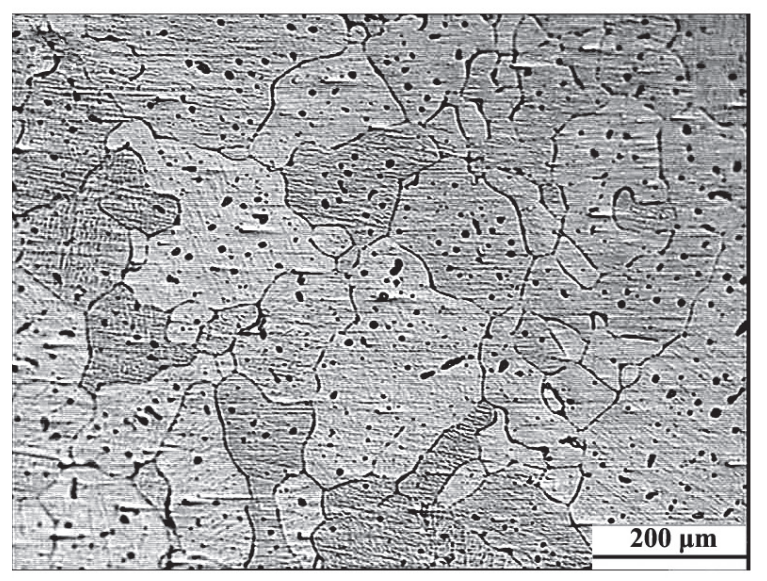

(e)

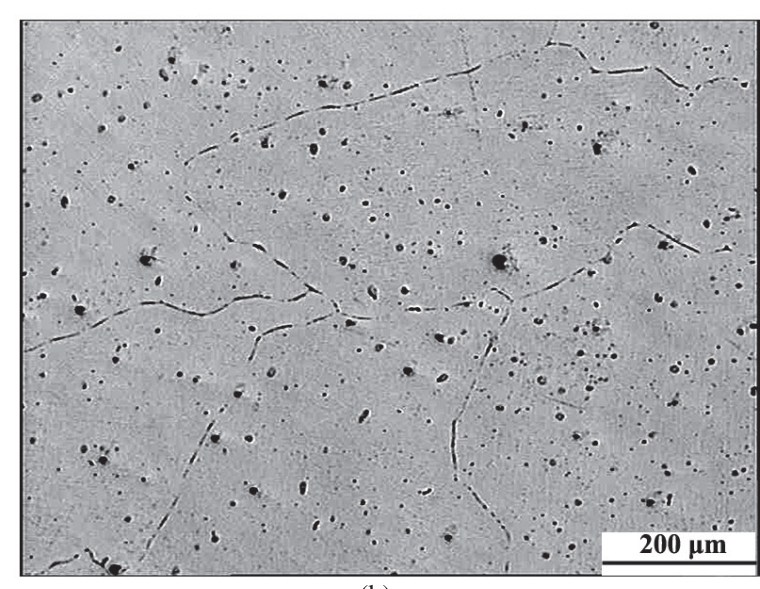

(b)

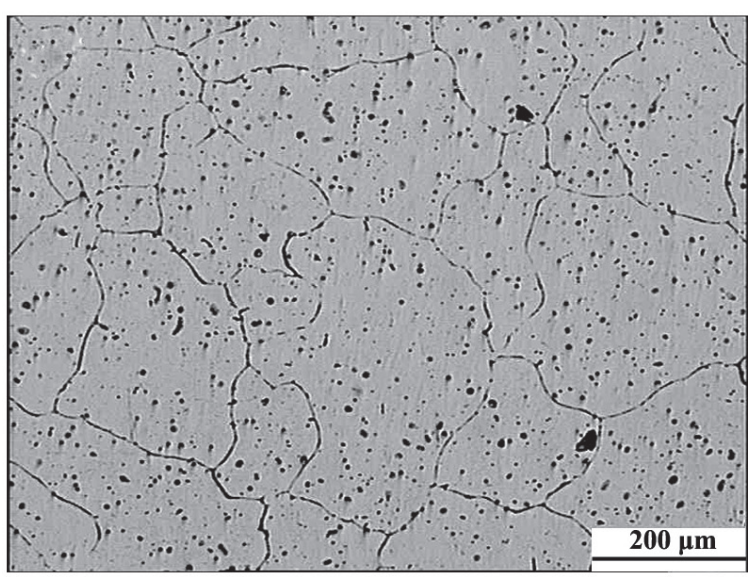

(d)

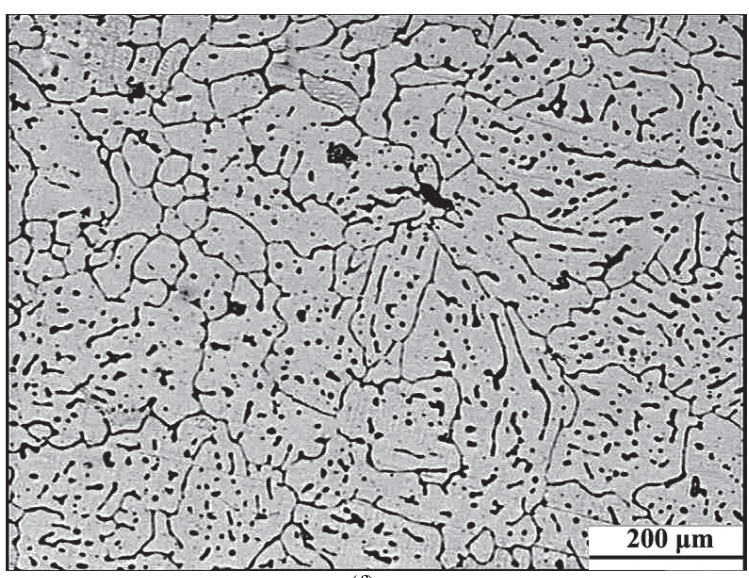

(f)

Figure 1. The microstructure of (a) pure magnesium and Mg-Ca alloys with (b) 0.7, (c) 1, (d) 2, (e) 3 and (f) 4 weight percent calcium content.

Table 3. The average grain diameter of pure $\mathrm{Mg}$ and as-cast $\mathrm{Mg}$-Ca alloys.

\begin{tabular}{ccccccc}
\hline Material & Mg & Mg-0.7Ca & Mg-1Ca & Mg-2Ca & Mg-3Ca & Mg-4Ca \\
\hline Average grain size $(\mathrm{mm})$ & 0.63 & 0.51 & 0.44 & 0.31 & 0.17 & 0.12 \\
\hline
\end{tabular}




\subsection{Hardness behavior}

The measured Vickers hardness value of the samples is shown in Figure 5. The hardness value of pure magnesium stood at $26.7 \mathrm{HV}$. The trend of hardness value shows an ascending behavior with increasing calcium content. A remarkable improvement in the hardness value of $\mathrm{Mg}-0.7 \mathrm{Ca}$ and $\mathrm{Mg}-1 \mathrm{Ca}$ alloys can mainly be attributed to the solid solution effect. The gradual increase in the hardness behavior of the other alloys with further increment of Ca content can be ascribed to the solid solution of calcium in magnesium

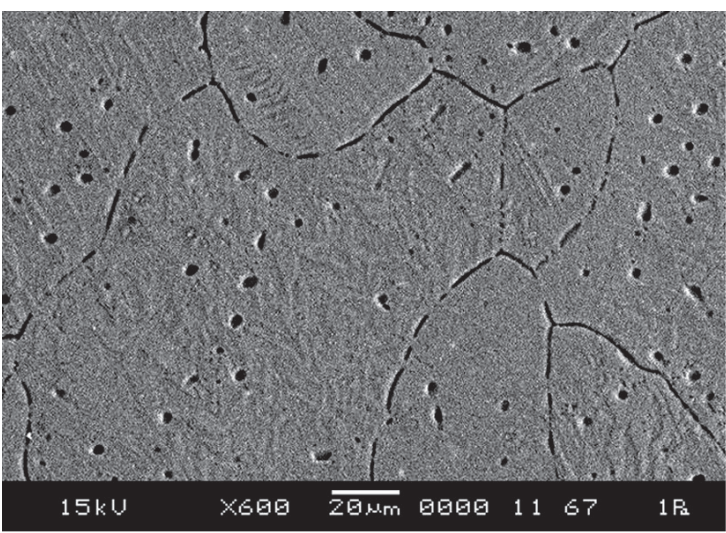

(a)

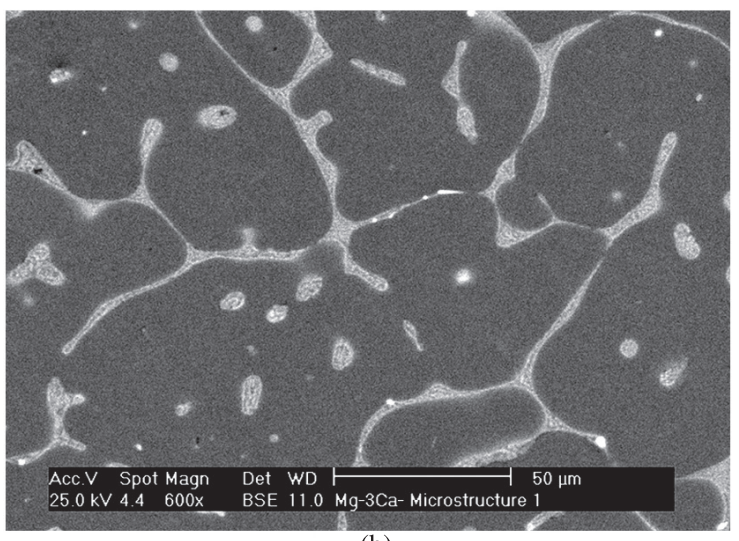

(b)

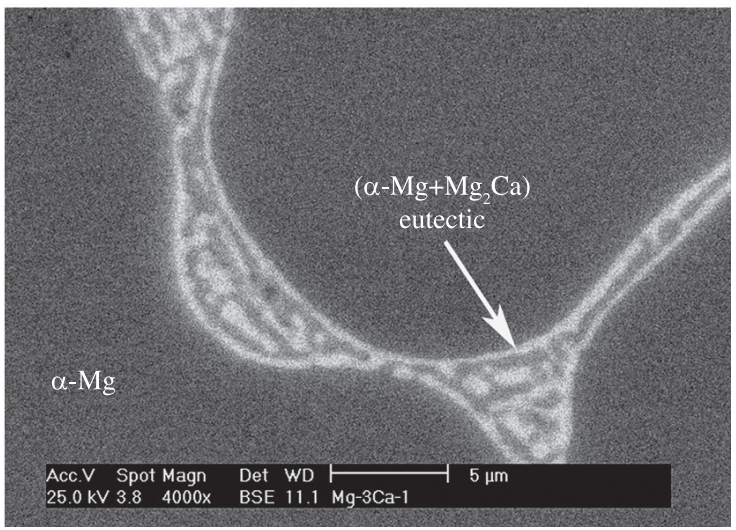

(c)

Figure 2. SEM images of (a) $\mathrm{Mg}-1 \mathrm{Ca}$ and (b) $\mathrm{Mg}-3 \mathrm{Ca}$ alloys and (c) the morphology of $\alpha-\mathrm{Mg}+\mathrm{Mg}_{2} \mathrm{Ca}$ eutectic phase in $\mathrm{Mg}^{-3} \mathrm{Ca}$ alloy. together with microstructure refinement and distribution of the $\mathrm{Mg}_{2} \mathrm{Ca}$ intermetallic phase in the microstructure. The latter had more pronounced effect on the hardness value due to the higher hardness of $\mathrm{Mg}_{2} \mathrm{Ca}$ phase as compared to $\alpha-\mathrm{Mg}$ matrix ${ }^{17}$.

\subsection{Immersion test}

Surface morphologies of $\mathrm{Mg}-\mathrm{Ca}$ alloys after immersion in SBF for 72 hours are exhibited in SEM images in Figure 6. It can be seen from Figures $6 a-c$ that no considerable amount of bio-corrosion products was formed on the surface of Mg-Ca alloys containing 0.7 to $2 \% \mathrm{Ca}$, respectively. It is believed that $\mathrm{Mg}(\mathrm{OH})_{2}$ film initially forms on the surface of the alloys as a result of magnesium dissolution in $\mathrm{SBF}^{18}$. Afterwards, this film gradually transforms to the hydrate state $\left(\mathrm{Mg}(\mathrm{OH})_{2} \cdot \mathrm{nH}_{2} \mathrm{O}\right)$ while being soaked in the solution. Removing the samples from SBF and drying them in air for analyzing the corrosion products by SEM/EDS caused dehydration which brought about shrinkage of the film and the formation of cracks as can be clearly seen in Figure 6c and $\mathrm{d}$. Prolonged soaking led to the emergence of randomly distributed white particles on the surface.

EDS analysis (Figure 7) shows that $\mathrm{Mg}, \mathrm{Ca}, \mathrm{P}$ and $\mathrm{O}$ are dominant constituent elements of the particles. These elements appeared in the form of relatively low soluble $\mathrm{Mg}_{3}\left(\mathrm{PO}_{4}\right)_{2}$ and $\mathrm{Ca}_{10}\left(\mathrm{PO}_{4}\right)_{6}(\mathrm{OH})_{2}$ compounds, important components of human bone, due to the bonding of $\mathrm{PO}_{4}^{3-}$ with $\mathrm{Ca}^{2+}$ and $\mathrm{Mg}^{2+}$ cations ${ }^{19}$. It has been reported that the white particle initiated and grew in localized pits formed on magnesium hydroxide film due to the attack of chloride ions $\left(\mathrm{Cl}^{-}\right)$in $\mathrm{SBF}^{20,21}$.

The white particle grew with increasing calcium content in the alloys due to the increment of $\mathrm{Mg}_{2} \mathrm{Ca}$ phase that results in producing more $\mathrm{Ca}^{2+}$ and $\mathrm{Mg}^{2+}$ cations in $\mathrm{SBF}^{22}$. The white particles, which are negatively charged apatite nuclei, absorb $\mathrm{Ca}^{2+}$ cations from the environment ${ }^{23}$. The resulted calcium-rich positively charged surface consumes $\mathrm{PO}_{4}{ }^{3-}$ anion of the fluid. The process continues sequentially to form bone-like and needle-shaped bone-like apatite which can be observed in the alloys containing 3 and $4 \%$ calcium, respectively (Figures $6 \mathrm{~d}$ and $\mathrm{f}$ ). This indicates that increasing calcium content accelerates the growth of bone-like and needle-shaped apatite in SBF. However, this is not an appropriate result as the $\mathrm{pH}$ value of the environment increases.

Figure 8 illustrates the increase in $\mathrm{pH}$ values of SBF for all tested samples for the whole duration of the immersion test, although the rate of $\mathrm{pH}$ value changes gradually decreased over time. The trend of $\mathrm{pH}$ values in the first 36 hours of immersion time was similar for all samples. It increased rapidly within the first 12 hours due to the rapid evolution of hydrogen gas during immersion in SBF which led to the accumulation of hydroxyl ion $\left(\mathrm{OH}^{-}\right)$near the sample surface. Afterwards, increasing the $\mathrm{pH}$ value of SBF adjacent to the surface of the sample interrupted the anodic reaction (Equation 1) and suppressed the production of $\mathrm{Mg}^{2+}$. At the same time, more cathodic reaction (Equation 2) occurred due to low corrosion resistance of the sample.

$\mathrm{Mg} \rightarrow \mathrm{Mg}^{2+}+2 \mathrm{e}$ 


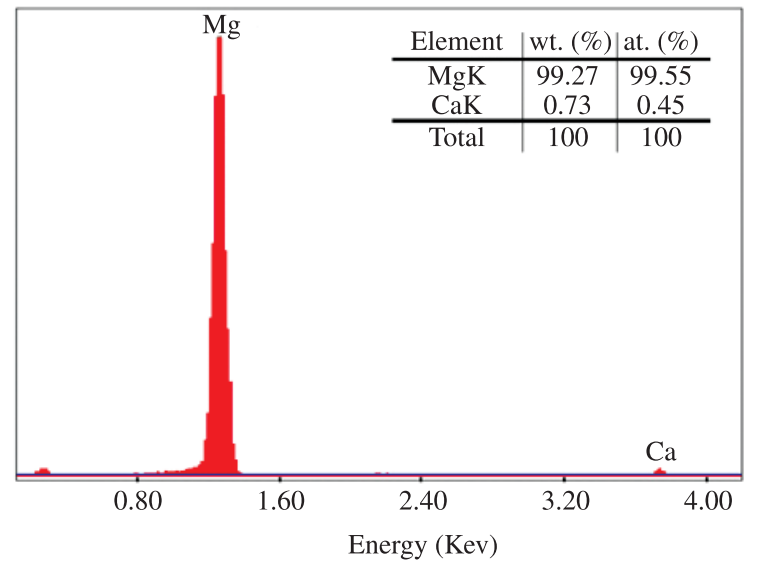

(a)

Figure 3. EDS analysis of (a) $\alpha$-matrix and (b) $\mathrm{Mg}_{2} \mathrm{Ca}$ phase.

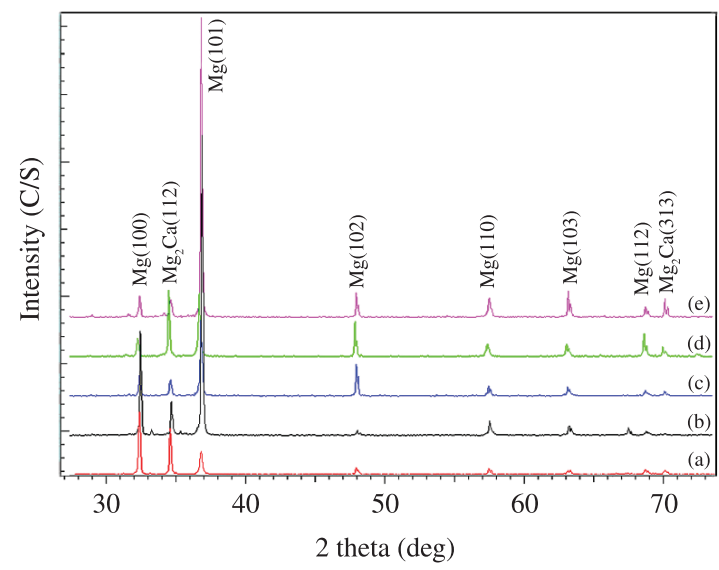

Figure 4. The XRD patterns of the Mg-Ca alloys with calcium content of (a) 0.7 , (b) 1, (c) 2, (d) 3 and (e) 4 weight percent calcium content.

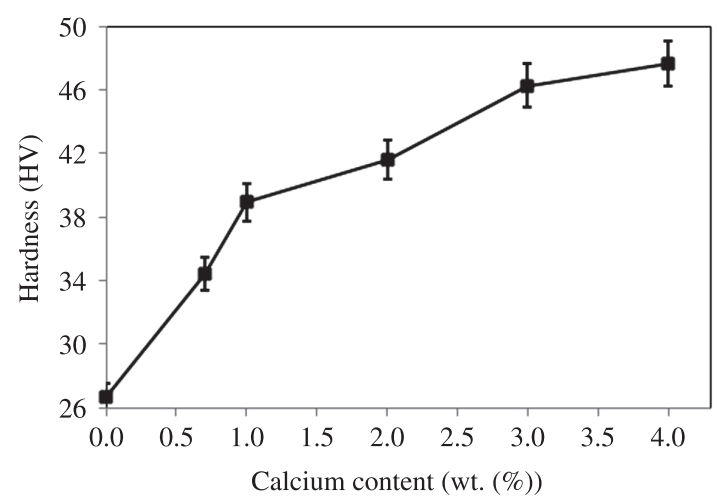

Figure 5. The hardness value of Mg-Ca alloys as a function of calcium content.

$2 \mathrm{H}_{2} \mathrm{O}+2 \mathrm{e} \rightarrow 2(\mathrm{OH})^{-}+\mathrm{H}_{2}$

This behavior was more severe for $\mathrm{Mg}-3 \mathrm{Ca}$ and $\mathrm{Mg}-4 \mathrm{Ca}$ alloys which resulted in rapidly generated bubbles. Precipitation of more $\mathrm{Mg}_{2} \mathrm{Ca}$ phase along the grain boundaries and interdenderic locations (Figure 2)

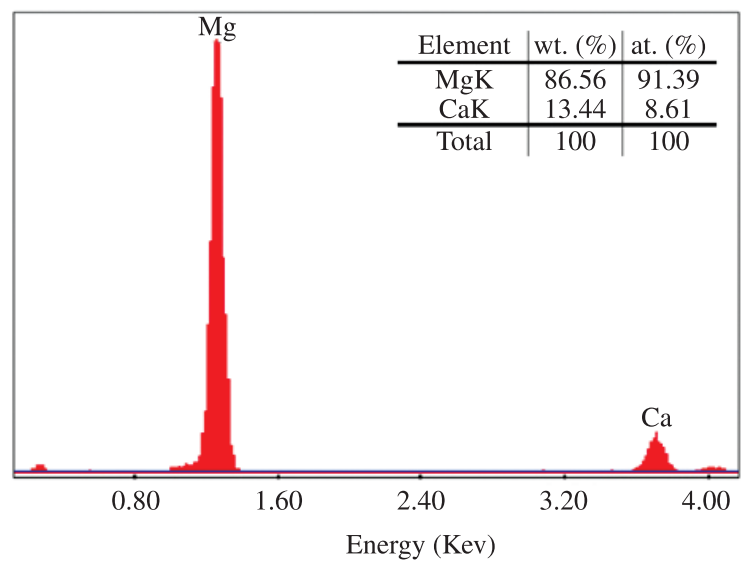

(b)

was the main reason for this behavior. In other words, higher percentage of $\mathrm{Ca}$ addition increased the surface area of the cathode $\left(\mathrm{Mg}_{2} \mathrm{Ca}\right)$. Subsequently the higher ratio of cathode/anode area resulted in higher corrosion of the alloys. Therefore, hydrogen evolution increased with more hydroxyl anion $\left(\mathrm{OH}^{-}\right)$produced causing an increase in $\mathrm{pH}$ values. On the other hand, formation of protective $\mathrm{Mg}(\mathrm{OH})_{2}$ layer on the surfaces of the sample (Equation 3) brought about slight reduction in the slope of the $\mathrm{pH}$ curve for the next 12 hours. This film was then attacked by chloride ions $\left(\mathrm{Cl}^{-}\right)$in the SBF causing pitting corrosion. Thus passivation was suppressed and $\mathrm{pH}$ value rose again for the following 12 hours. The white particles started to form in the pits for the tested samples according to Equation 4. This reduced the degradation of the alloys which led to the decrease of the curves slope for the next interval.

$\mathrm{Mg}+2 \mathrm{H}_{2} \mathrm{O} \rightarrow \mathrm{Mg}(\mathrm{OH})_{2+} \mathrm{H}_{2}$

$6 \mathrm{PO}_{4}^{3-}+10 \mathrm{Ca}^{2+}+2 \mathrm{OH}^{-} \rightarrow \mathrm{Ca}_{10}\left(\mathrm{PO}_{4}\right)_{6}(\mathrm{OH})_{2}$

For the samples containing $0.7,1$ and $2 \%$ calcium, $\mathrm{pH}$ variations remained almost unchanged for the rest of the soaking time. However, $\mathrm{pH}$ value of the solution decreased for the alloys containing 3 and $4 \%$ calcium. These samples produced more $\mathrm{Ca}^{2+}$ cation which consumes $\mathrm{PO}_{4}^{3-}$ anion during the formation of bone-like apatite. The preferential growth of the process product formed needle-shaped bone-like apatite. It is believed that this type of apatite is governed by higher $\mathrm{pH}$ values ${ }^{24}$ which accelerate biodegradability of $\mathrm{Mg}$-Ca alloys. On the other hand, increasing $\mathrm{pH}$ value causes haemolysis problem in human ${ }^{25,26}$ and should be controlled. From the above results it can be deduced that $\mathrm{Mg}-0.7 \mathrm{Ca}$ alloy causes the least $\mathrm{pH}$ alteration in the human body. Comparing $\mathrm{pH}$ value of the samples, it can be seen that the $\mathrm{pH}$ variations of pure $\mathrm{Mg}$ as well as $\mathrm{Mg}-3 \mathrm{Ca}$ and $\mathrm{Mg}-4 \mathrm{Ca}$ alloys are higher than those of other experimented $\mathrm{Mg}$-Ca alloys. Improving corrosion resistance of $\alpha$-matrix by solid solution of $\mathrm{Ca}$ in $\mathrm{Mg}$ which slowed down the generation rate of $\mathrm{OH}^{-}$is the main reason for their lower amount of $\mathrm{pH}$ values. 


\subsection{Electrochemical measurements}

Figure 9 shows the electrochemical polarization curves of the pure magnesium as well as the five investigated alloys. The polarization curves in the figure represent similar mechanism of electrochemical behaviors for all the samples.
The data derived from the curves, $\mathrm{E}_{\text {corr }}, \mathrm{I}_{\text {corr }}$ and corrosion rate, are summarized in Table 4.

The results indicate that adding $0.7 \% \mathrm{Ca}$ to pure $\mathrm{Mg}$ increased the corrosion potential towards more cathodic values due to higher electronegativity of $\mathrm{Ca}$ compared to that of $\mathrm{Mg}$. However, further increase of calcium content

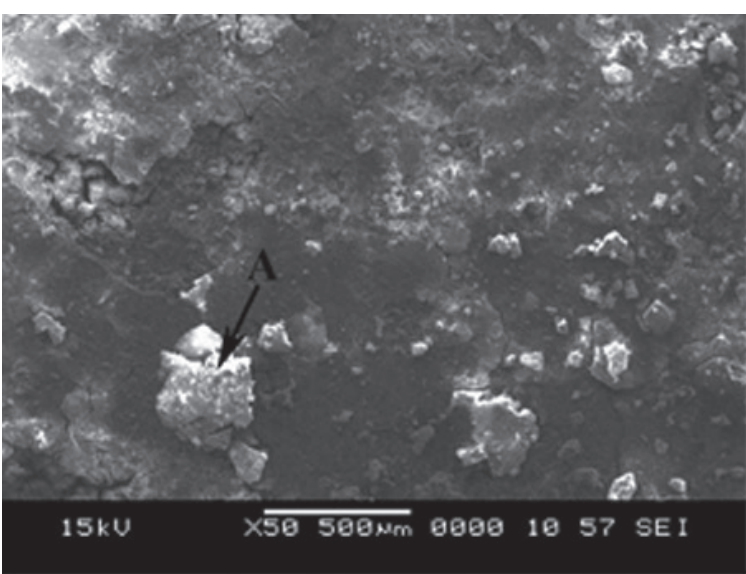

(a)

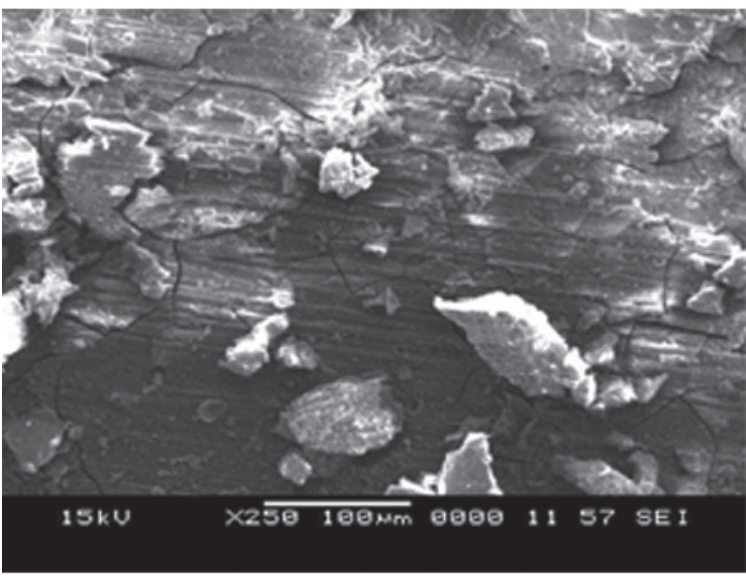

(c)

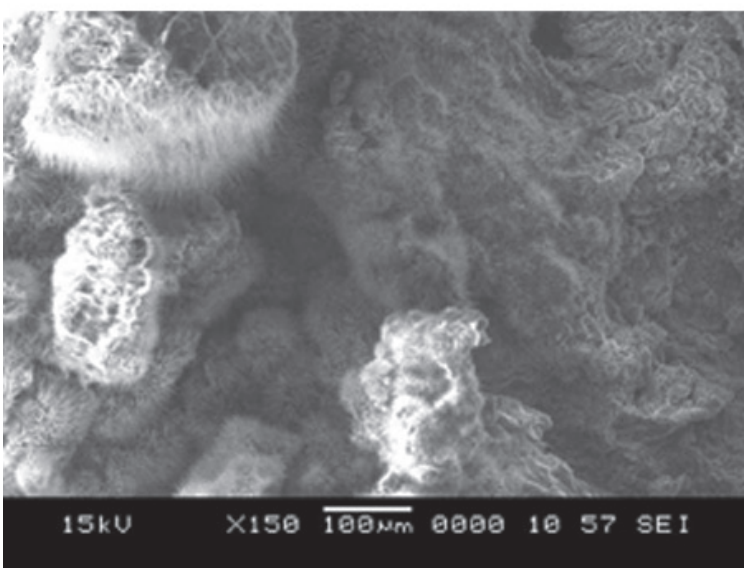

(e)

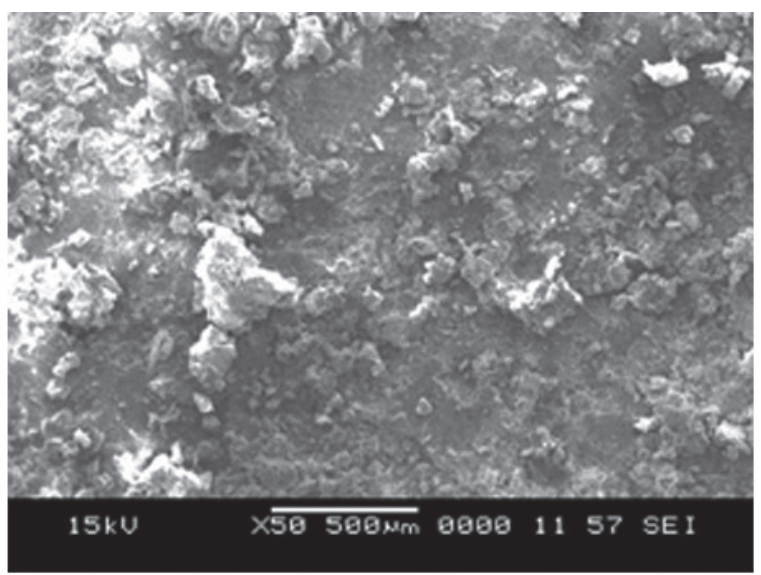

(b)

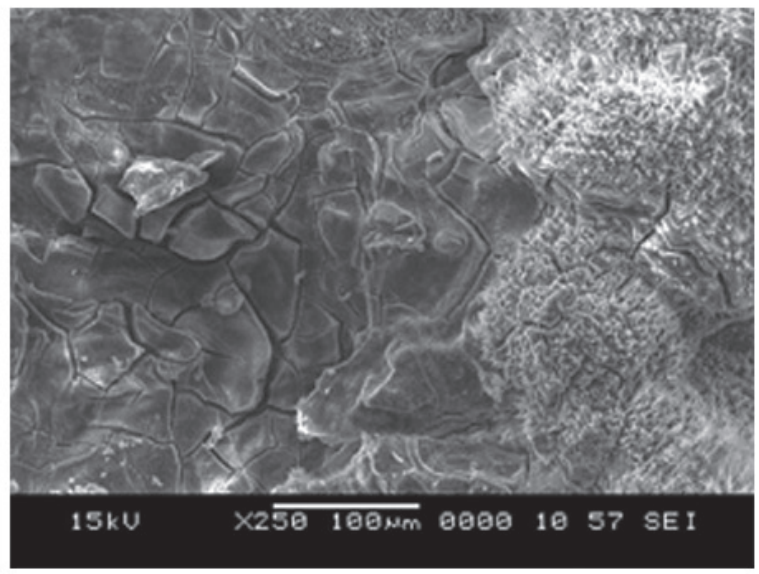

(d)

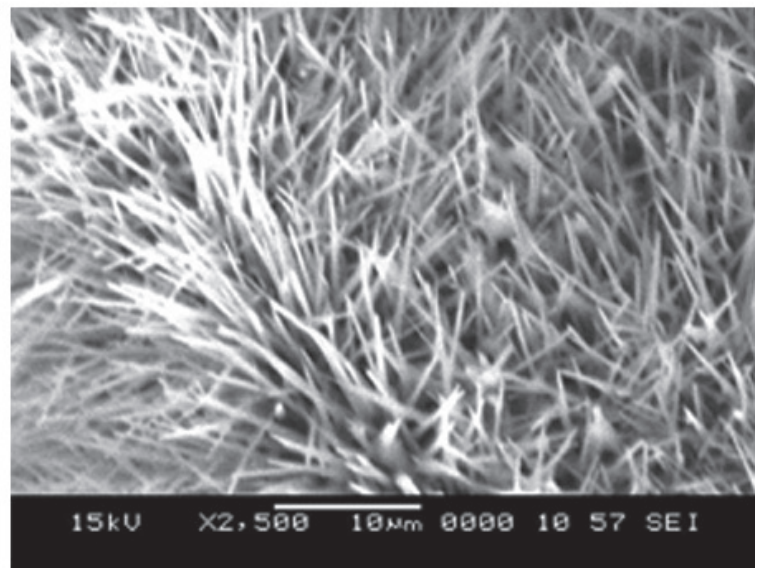

(f)

Figure 6. SEM image of Mg-Ca alloy with (a) 0.7, (b) 1, (c) 2, (d) 3, (e) 4 Ca; and (f) needle-shaped bone like apatite formed on Mg-4Ca alloy after soaking in SBF for 72 hours. 
Table 4. Electrochemical data of the samples in Kokubo solution.

\begin{tabular}{lccc}
\hline Sample & $\begin{array}{c}E_{\text {corr }} \\
(\mathbf{V})\end{array}$ & $\begin{array}{c}\mathbf{i}_{\text {corr }} \\
\left(\mathbf{A . c m}^{-2} \times \mathbf{1 0}^{\mathbf{3}}\right)\end{array}$ & $\begin{array}{c}\text { Corrosion } \\
\text { rate }(\mathbf{m p y})\end{array}$ \\
\hline $\mathrm{Mg}$ & -2.03 & 3.09 & 2170 \\
$\mathrm{Mg}-0.7 \mathrm{Ca}$ & -1.90 & 1.97 & 1479 \\
$\mathrm{Mg}-1 \% \mathrm{Ca}$ & -1.96 & 2.24 & 1876 \\
$\mathrm{Mg}-2 \% \mathrm{Ca}$ & -1.99 & 3.12 & 2017 \\
$\mathrm{Mg}-3 \% \mathrm{Ca}$ & -2.05 & 3.95 & 2881 \\
$\mathrm{Mg}-4 \% \mathrm{Ca}$ & -2.06 & 4.70 & 3604 \\
\hline
\end{tabular}

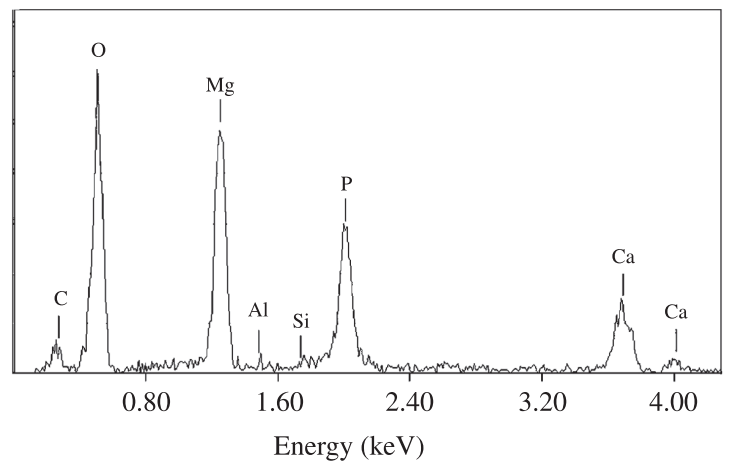

Figure 7. EDS analysis of point $\mathrm{A}$ in Figure 6a.

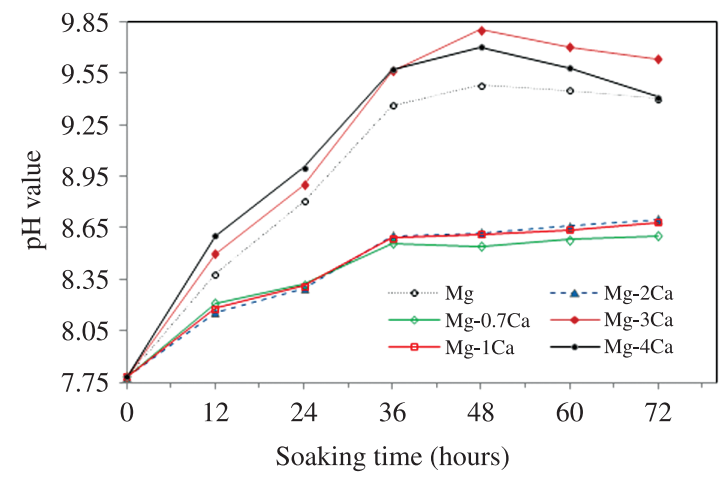

Figure 8. The $\mathrm{pH}$ value of $\mathrm{SBF}$ solutions plotted against immersion time for the pure $\mathrm{Mg}$ and investigated $\mathrm{Mg}$-Ca alloys.

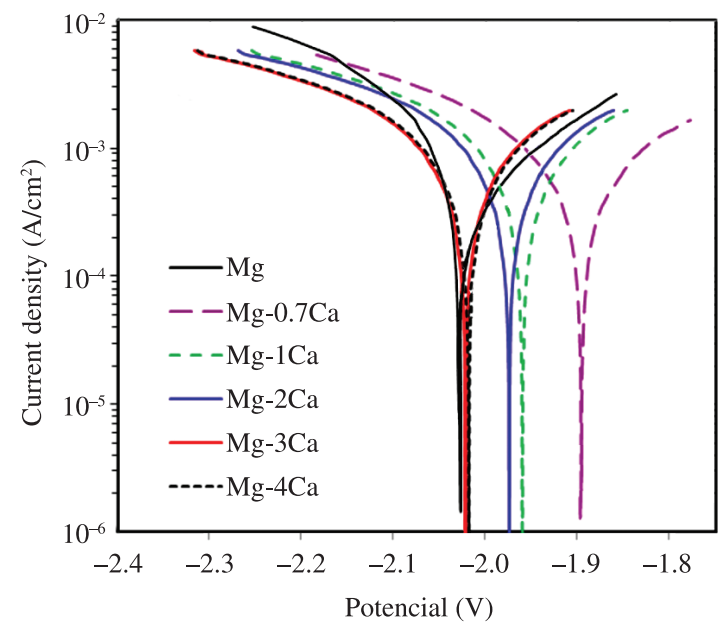

Figure 9. Tafel curves of the pure $\mathrm{Mg}$ and as-cast $\mathrm{Mg}-\mathrm{Ca}$ alloys in SBF. shifted the corrosion potential of the alloy towards more anodic position. This indicates that the corrosion potential of the samples reduced with additional calcium content, while the current density and corrosion rate of the alloys increased. As previously mentioned, formation of more amount of $\mathrm{Mg}_{2} \mathrm{Ca}$ with addition of higher $\mathrm{Ca}$ percentage diminished the corrosion resistance of $\mathrm{Mg}-\mathrm{Ca}$ alloy. In other words, corrosion resistance of pure magnesium was improved by the addition of $0.7 \% \mathrm{Ca}$ due to the low volume fraction of $\mathrm{Mg}_{2} \mathrm{Ca}$ phase and less grain boundary. In addition, the results given in Table 4 indicate that pure $\mathrm{Mg}$ almost behaves like $\mathrm{Mg}-2 \mathrm{Ca}$ alloy in terms of corrosion properties. Moreover, from the curves given in Figure 9, it can be observed that the cathodic polarization curve corresponding to hydrogen evolution reaction was lower on $\mathrm{Mg}-0.7 \mathrm{Ca}$ alloy compared to that of other samples. This suggests that it was more difficult for the cathodic reaction (Equation 2) to kinetically take place for this alloy due to lower over potential of hydrogen evolution. Therefore, $\mathrm{Mg}-0.7 \mathrm{Ca}$ showed more resistance to corrosion in $\mathrm{SBF}$ and can be a good candidates for bio-implant applications.

\section{Conclusion}

The aim of this research was to study the effect of calcium content on the microstructure, hardness value and corrosion behavior of $\mathrm{Mg}$-xCa binary alloys. The following results can be drawn:

- Increasing the calcium content caused microstructure refinement and raised the volume fraction of $\mathrm{Mg}_{2} \mathrm{Ca}$ phase distributed in $\alpha-\mathrm{Mg}$ matrix, among the interdendrite areas and along grain boundaries of $\mathrm{Mg}-\mathrm{Ca}$ binary alloy which resulted in an increase in hardness value.

- The $\mathrm{pH}$ value of SBF was decreased by addition of $\mathrm{Ca}$ to pure magnesium. However, increasing calcium content in $\mathrm{Mg}-\mathrm{Ca}$ binary alloy showed inverse behavior.

- Bone-like appetite growth was observed in $\mathrm{Mg}-3 \% \mathrm{Ca}$ alloy, whilst the form of growth changed to needleshaped bone-like for $\mathrm{Mg}-4 \% \mathrm{Ca}$ alloy after 72 hours soak in SBF, showing that increasing calcium content accelerates the growth of bone-like and needle-shaped apatite.

- Addition of calcium increased corrosion resistance of pure magnesium in SBF. However, increasing $\mathrm{Ca}$ content resulted in decreasing corrosion potential towards more anodic positions which accelerated the degradation rate of $\mathrm{Mg}$ - $\mathrm{Ca}$ alloys due to the rapid degradation of $\mathrm{Mg}_{2} \mathrm{Ca}$ phase.

- Mg-0.7Ca alloy indicated better performance among the investigated alloys which suggests its use as a biodegradable material in bio-implant applications.

\section{Acknowledgements}

This study was sponsored by the Ministry of Higher Education of Malaysia (Vote no. 78610). The authors are thankful to the Faculty of Mechanical Engineering, Universiti Teknologi Malaysia for providing resources and facilities. 


\section{References}

1. Seal CK, Vince K and Hodgson MA. Biodegradable surgical implants based on magnesium alloys- a review of current research IOP Conf. Materials Science and Engineering. 2009; 4:012011.

2. Wang HX, Guan SK, Wang X, Ren CX and Wang LG. In vitro degradation and mechanical integrity of Mg-Zn-Ca alloy coated with Xa-deficient hydroxyapatite by the pulse electrodeposition process. Acta Biomaterialia. 2010; 6:1743-1748. PMid:20004746. http://dx.doi.org/10.1016/j.actbio.2009.12.009

3. Zeng RC, Dietzel W, Witte F, Hort N and Blawert C. Progress and challenge for magnesium alloys as biomaterials. Advanced Engineering Materials. 2008; 10:B3-14. http://dx.doi. org/10.1002/adem.200800035

4. Koleini S, Idris MH and Jafari H. Influence of hot rolling parameters on microstructure and biodegradability of $\mathrm{Mg}-1 \mathrm{Ca}$ alloy in simulated body fluid. Materials and Design. 2012; 33:20-25. http://dx.doi.org/10.1016/j. matdes.2011.06.063

5. Müller WD, Nascimento ML, Zeddies M, Córsico M, Gassa LM and Mele MAFL. Magnesium and its alloys as degradable biomaterials, Corrosion studies using potentiodynamic and EIS electrochemical techniques. Materials Research. 2007; 10:5-10.

6. Kim WC, Kim JG, Lee JY and Seok HK. Influence of Ca on the corrosion properties of magnesium for biomaterials. Materials Letters. 2008; 62:4146-4148. http://dx.doi.org/10.1016/j. matlet.2008.06.028

7. Zhang S, Zhang X, Zhao C, Li J, Song Y and Xie C. Research on an Mg-Zn alloy as a biodegradable biomaterial. Acta Biomaterialia. 2010; 6:626-640. PMid:19545650. http://dx.doi. org/10.1016/j.actbio.2009.06.028

8. Witte F, Kaese V, Switzer H, Meyer-Lindenberg A, Wirth CJ and Windhag $\mathrm{H}$. In vivo corrosion of four magnesium alloys and the associated bone response. Biomaterials. 2005; 26:3557-3563. PMid:15621246. http://dx.doi.org/10.1016/j. biomaterials.2004.09.049

9. Witte F, Fischer J, Nellesen J, Crostack H, Kaese V, Pischd A et al. In vitro and in vivo corrosion measurements of magnesium alloys. Biomaterials. 2006; 27:1013-1018. PMid:16122786. http://dx.doi.org/10.1016/j.biomaterials.2005.07.037

10. El-Rahman SSA. Neuropathology of aluminum toxicity in rats (glutamate and GABA impairment). Pharmacological Research. 2003; 47:189-194. http://dx.doi.org/10.1016/S10436618(02)00336-5

11. Yumiko N, Yukari T, Yasuhid T, Tdashi S and Yoshio L. Differences in behavior among the chlorides of seven rare earth elements administered intravenously to rats. Fundamental and Applied Toxicology. 1997; 37:106-116. PMid:9242583. http:// dx.doi.org/10.1006/faat.1997.2322

12. Xu LP, Yu GN, Zhang E, Pan F and Yang K. In vivo corrosion behavior of $\mathrm{Mg}-\mathrm{Mn}-\mathrm{Zn}$ alloy for bone implant application. Journal of Biomedical Materials Research A. 2007; 83:703-711. PMid:17549695. http://dx.doi. org/10.1002/jbm.a.31273

13. Li Z, Gu X, Lou S and Zheng Y. The development of binary $\mathrm{Mg}$-Ca alloys for use as biodegradable materials within bone. Biomaterials. 2008; 29:1329-1344. PMid:18191191. http:// dx.doi.org/10.1016/j.biomaterials.2007.12.021
14. Lee CD, Kang CS and Shin KS. Effect of galvanic corrosion between precipitate and matrix on corrosion behavior of as-cast magnesium-aluminum alloys. Metals and Materials International. 2000; 6:351-358. http://dx.doi.org/10.1007/ BF03028082

15. Salahshoor M and Guo YB. Surface integrity of biodegradable Magnesium-Calcium orthopedic implant by burnishing. Journal of the Mechanical Behavior of Biomedical Materials. 2011; 4:1888-1904. PMid:22098888. http://dx.doi. org/10.1016/j.jmbbm.2011.06.006

16. Jalota S, Bhaduri SB and Tas AC. Using a synthetic body fluid (SBF) solution of $27 \mathrm{mM} \mathrm{HCO}_{3}^{-}$to make bone substitutes more Osteointegrative. Materials Science and Engineering C. 2008; 28:129-140. http://dx.doi.org/10.1016/j. msec.2007.10.058

17. Piatti G and Stoto T. Superplasticity of the $\mathrm{Mg}$-Ca eutectic alloy. Materials Science Letters. 1984; 3:60-64. http://dx.doi. org/10.1007/BF00720076

18. Ye X, Chen M, Yang M, Wei J and Liu D. In vitro corrosion resistance and cytocompatibility of nano-hydroxyapatite reinforced $\mathrm{Mg}-\mathrm{Zn}-\mathrm{Zr}$ composites. Journal of Materials Science: Materials in Medicine. 2010; 21:1321-1328. PMid:20012772. http://dx.doi.org/10.1007/s10856-009-3954-3

19. Song Y, Shan D, Chen R, Zhang F and Han EH. Biodegradable behaviors of AZ31 magnesium alloy in simulated body fluid. Materials Science and Engineering C. 2009; 29:1039-1045. http://dx.doi.org/10.1016/j.msec.2008.08.026

20. Gu X, Zheng Y, Zhong S, Xi T, Wang J and Wang W. Corrosion of, and cellular responses to $\mathrm{Mg}-\mathrm{Zn}-\mathrm{Ca}$ bulk metallic glasses. Biomaterials. 2010; 31:1093-1103. PMid:19939446. http:// dx.doi.org/10.1016/j.biomaterials.2009.11.015

21. Pardo A, Merino MC, Coy AE, Arrabal R, Viejo F and Matykina E. Corrosion behaviour of magnesium/aluminium alloys in 3.5 wt.\% NaCl. Corrosion Science, 2008; 50:823-834. http://dx.doi.org/10.1016/j.corsci.2007.11.005

22. Zhang E and Yang L. Microstructure, mechanical properties and bio-corrosion properties of $\mathrm{Mg}-\mathrm{Zn}-\mathrm{Mn}-\mathrm{Ca}$ alloy for biomedical application. Materials Science and Engineering A. 2008; 497:111-118. http://dx.doi.org/10.1016/j. msea.2008.06.019

23. Kim HM, Himeno T, Kawashita M, Kokubo T and Nakanura T. The mechanism of biomineralization of bone-like apatite on synthetic hydroxyapatite: an in vitro assessment. Journal of the Royal Society Interface. 2004; 1:17-22. PMid:16849149 PMCid:1618931. http://dx.doi.org/10.1098/rsif.2004.0003

24. Tomozawa M and Hiromoto S. Growth mechanism of hydroxyapatite-coatings formed on pure magnesium and corrosion behavior of the coated magnesium. Applied Surface Science. 2011; 257:8253-8257. http://dx.doi.org/10.1016/j. apsusc.2011.04.087

25. Harandi SE, Idris MH and Jafari H. Effect of forging process on microstructure, mechanical and corrosion properties of biodegradable $\mathrm{Mg}-1 \mathrm{Ca}$ alloy. Materials and Design. 2011; 32:2596-2603. http://dx.doi.org/10.1016/j. matdes.2011.01.042

26. Zhang E, Yang L, Xu J and Chen H. Microstructure, mechanical properties and bio-corrosion properties of $\mathrm{Mg}-\mathrm{Si}(-\mathrm{Ca}, \mathrm{Zn})$ alloy for biomedical application. Acta Biomaterialia. 2010; 6:1756-1762. PMid:19941979. http:// dx.doi.org/10.1016/j.actbio.2009.11.024 